\title{
Coronavirus: Public Arabic Twitter Dataset
}

\author{
Aseel Addawood \\ Information Science Department, Imam Mohammad Bin Saud University \\ Department of Informatics, University Illinois at Urbana-Champaign \\ aasdawood@imamu.edu.sa
}

\begin{abstract}
The COVID-19 pandemic spread of the coronavirus across the globe has affected our lives on many different levels. The world we knew before the spread of the virus has become another one. Every country has taken preventive measures, including social distancing, travel restrictions, and curfew, to control the spread of the disease. With these measures implemented, people have shifted to social media platforms in the online sphere, such as Twitter, to maintain connections. In this paper, we describe a coronavirus data set of Arabic tweets collected from January 1, 2020, primarily from hashtags populated from Saudi Arabia. This data set is available to the research community to glean a better understanding of the societal, economical, and political effects of the outbreak and to help policy makers make better decisions for fighting this epidemic.
\end{abstract}

\section{Introduction}

After the wide spread of the coronavirus (COVID-19) began, the World Health Organization declared it a pandemic on January 30, 2020 (World Health Organization and others, 2020). The first case was reported as originating in the city of Wuhan, China, where the government had to quarantine the whole city to overcome the quick spread of the disease. However, with globalization and the way the modern world functions, the pandemic has affected 213 countries, with more than one and a half million confirmed cases to date (World Health Organization and others, 2020).

This spread has led governments around the globe to start implementing crisis management plans and pandemic control strategies. Although governments and public health authorities may implement prevention measures and control policies, the public plays a vital role in following these measures to contain the spread of the disease.

The most important measures used to combat the spread of the virus are limiting physical contact between people and reducing the time people spend next to one another. People now rely more on the internet and online platforms to continue their social interactions. One of the most widely used social media platforms is Twitter, popular for its accessibility and ease of information sharing.

In this work, we focus on Arabic online conversation because Arabic is ranked fourth among the top 10 languages used on the web ${ }^{1}$. The main focus in the data set collected was on hashtags used in Saudi Arabia, although they might be used in Arabic-speaking countries outside of Saudi Arabia. Saudi Arabia is among the countries with the highest number of Twitter users among its online population (Clement, 2020; Puri-Mirza, 2019). Moreover, Saudi Arabia produces $40 \%$ of all tweets in the Arab world (Mourtada and Salem, 2014).

The data set shared is divided into conversations discussing the precautionary measures governments have applied, conversations showing social solidarity, and conversations supporting decisions governments have taken. The data set also contains data from three Saudi official accounts. The total number of tweets collected so far is 3.8 million.

Policy and decision makers can use the described data set to understand people's engagement in social media and to track the spread of misinformation.

In the following sections we describe data collection, data set statistics, and information about how to access the data set.

\section{Data Collection and Description}

The data collection started by identifying a list of trending hashtags and key words mostly used by the public. We used Crimson Hexagon, ${ }^{2}$, which is a social media analytic platform that provides paid data stream access. This tool allowed us to obtain tweets and retweets discussing the epidemic in Arabic. We collected data starting from January 1, 2020, until April 10, 2020, collecting 3.8 million tweets until that date. More data will be collected as the project continues.

To capture conversations related to the epidemic and people's reactions toward it, we continuously observed trending topics and hashtags. Around 70 keywords and hashtags were selected; these were later categorized based on how they oriented the conversations because this is the main purpose of hashtags. Table 1 lists hashtags that mainly discuss precautionary measures governments have applied. These include discussions of curfew, business closures, and travel restrictions.

Table 2 lists hashtags that show some kind of social solidarity within the community after applying such prevention

\footnotetext{
${ }^{1}$ https://www.internetworldstats.com/stats7.htm

${ }^{2}$ https://www.crimsonhexagon.com/
} 
Table 1: Hashtags discussing precautionary measures applied by governments

\begin{tabular}{|c|c|c|}
\hline Hashtags & English translation & Number of Tweets \\
\hline إيقاف _صلاة _الجماعة & Stopping congregational prayer & 7502.00 \\
\hline إغلاق ــالحدائق & Gardens closure & 180.00 \\
\hline صلوا _في ـرحالكى & Pray in your travel & 37997.00 \\
\hline ايقاف _الصلاة _بالمسجد & Stop praying in the mosque & 2953.00 \\
\hline ايقاف _صلاة _الجمعة _والجماعة & Stopping Friday and group prayers & 79.00 \\
\hline إغلاق _محلات _الحلاقة & barber shops closure & 686.00 \\
\hline اغلاق _المقاهي & Cafes closure & 30.00 \\
\hline اغلاق _الصالونات & Salons closure & 13466.00 \\
\hline ايقاف _الدوري & Stopping football league & 18923.00 \\
\hline تعليق _النشاط _الرياضي & Sports suspension & 2824.00 \\
\hline تعليق _الرحلات _الدولية & International flights suspended & 102.00 \\
\hline تعليق _الرحلات _الداخليه & Internal flights suspended & 94.00 \\
\hline تعليق _العمل & Work suspension & 35170.00 \\
\hline تعليق _الدراسة & School Suspension & 127064.00 \\
\hline اغلاق _النوادي _الرياضية & Gym closure & 1625.00 \\
\hline-- & Close the malls in Saudi Arabia & 7614.00 \\
\hline إغلاق _المجمعات _التجارية & Close the commercial complexes & 239.00 \\
\hline تعليق _القطاع _ـالخاص & private sector suspension & 18962.00 \\
\hline منع _التجول & Curfew & 199925.00 \\
\hline منع _التنقل _بين _المناطق & Prevent movement between regions & 16908.00 \\
\hline
\end{tabular}

Table 2: Hashtags showing social solidarity

\begin{tabular}{|c|c|c|}
\hline Hashtags & English translation & Number of Tweets \\
\hline المسافة _ما _تفرقنا & distance does not separates us & 35,498 \\
\hline نتفرق _لصحتنا & Lets Separate for our health & 27,612 \\
\hline احنا _قدها & We can do it & 8,889 \\
\hline سحابة _وتعدي & A cloud and it will pass & 18,800 \\
\hline يارب _ارفع _عنا _البلاء & Oh Lord, raise us from calamity & 72,401 \\
\hline مبادرة _أنتم _أبطال & You are a champion initiative & 1,440 \\
\hline تجارنا _فيهم _الخير & Our merchants are good & 27,714 \\
\hline ابطال _الصحة _بكى _نفخر & Health champions we are proud of you & 12,720 \\
\hline البيض _متوفر & Eggs_available & 14,694 \\
\hline
\end{tabular}

measures as social distancing. This category includes such hashtags as "distance does not separate us."

Table 3 lists hashtags that show support for the decisions and prevention measures governments have taken. This group includes hashtags encouraging people to stay home, exercise at home, or enjoy their time while in quarantine.

Table 5 lists hashtags populated by Saudi governmental Twitter accounts. These hashtags urge the community to be responsible about decreasing the number of cases by following prevention measures, reassure the community about the availability of products, and answer common questions about COVID-19. The table shows the list of hashtags accompanied by the governmental account from where they started.

One of the main ways to overcome misinformation is to take information from known, reputable sources. In social media, the most reliable sources are governmental sources. Table 4 below lists the Saudi Arabia Ministry of Health accounts and the number of tweets collected for each account.

Preliminary statistics are given in Table 6. The table shows the number of tweets, the number of retweets, the
Table 3: Hashtags supporting decisions taken by the government

\begin{tabular}{|c|c|c|}
\hline Hashtags & English translation & Number of Tweets \\
\hline اسبوعين _فقط & Only two weeks & 29,355 \\
\hline تمرينك _ببيتك & Exercise at home & 2,538 \\
\hline بيتك _ناديك & Your home is your gym & 5,425 \\
\hline بتمرن _بالبيت & Exercise at home & 40,196 \\
\hline اجلس _بالبيت & Sit at home & 69,065 \\
\hline قهوتك -في -بيتك & Your coffee in your home & 696 \\
\hline نيهيًا _صفر & We want it zero & 94,627 \\
\hline المملكة _تستاهل _اكثر & The kingdom deserves more & 51,914 \\
\hline كلنا _مسؤول _عن _الوطن & We are all responsible for the country & 5,479 \\
\hline لبيه ــياوطن & To him, my homeland & 17,572 \\
\hline اكثر _شي _سويته _بالحجر _المنزلي & The most thing you did in the Quarantine & 30,911 \\
\hline الحجّر ـالمنزلي & Quarantine is a national duty & 55,942 \\
\hline 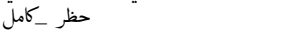 & Curfew & 82,349 \\
\hline كلنا _بالبيت _لاجل _السعوديه & We are all home for Saudi Arabia & 34,340 \\
\hline حظر _التجول _الكامل & Curfew & 37,862 \\
\hline جبر -كمل & Curfew & 15,579 \\
\hline قاعد _بالبيت & Staying home & 64,355 \\
\hline خلك _بالبيت & Stay home & 177,619 \\
\hline خلك -في ـالبيت & Stay home & 220,759 \\
\hline انثبروا" -ببيوتكى & Stay home & 30,683 \\
\hline حظر _التجول _في _السعودية & Curfew in Saudi Arabia & 36,292 \\
\hline وضعنا _مع _الحجر & Our situation with Quarantine & 21,059 \\
\hline استراحتي -في -بيتي & My rest in my home & 5,479 \\
\hline نشاطي -في _منزلي & My activity in my home & 22,750 \\
\hline فعاليات _ألحجر" _الصحي" & Quarantine activities & 24,239 \\
\hline الحجر ـالمنزلي & Quarantine & 362,132 \\
\hline كنا _في _البيت _لاجل _السعودية & We are all at home for Saudi Arabia & 77,021 \\
\hline الزم _بيتك _حايه _لك _ولمجتمعك & stay home for you and your community safety & 31,584 \\
\hline الحجر ـالصحي & Quarantine & 141,311 \\
\hline اعزل _نفسآك & Isolate yourself & 25,344 \\
\hline
\end{tabular}

Table 4: Saudi Arabia ministry of health accounts

\begin{tabular}{cc}
\hline Account name & Number of Tweets \\
\hline @ spokesman_moh & 66 \\
LiveWellMOH & 637 \\
@SaudiMOH & 897 \\
\hline
\end{tabular}

Table 5: Hashtags populated by Saudi governmental accounts

\begin{tabular}{|c|c|c|c|}
\hline Hashtags & English translation & Account & Number of Tweets \\
\hline الوقاية _من _كورونا & Corona Prevention & @SaudiMOH & 293,123 \\
\hline كلنا _مسؤول & We are all responsible & @ spokesman_moh & 596,288 \\
\hline عش _بصحة & Live healthily & LiveWellMOH & 28,541 \\
\hline أسئلة _كورونا & Corona's Questions & @SaudiMOH & 15,455 \\
\hline أبطال _الصحة & Health Heroes & KSAMOFA & 155,770 \\
\hline أبطال _المجتمع & Community Heroes & @SaudiMOH & 16,641 \\
\hline المنتجات _متوفرة & Products available & $@$ MCgovSA & 22,992 \\
\hline الخدمات _مستمرة & Services continuous & $@$ MCgovSA & 4,501 \\
\hline متر ـونص & One and a half meters & @SaudiMOH & 8,616 \\
\hline شكراً _أبطال _التعليم & Thanks Education heroes & @ moe_gov_sa & 18,227 \\
\hline الدراسة _مستمرةٍ & Schools are continuing & @ moe_gov_sa & 152,901 \\
\hline
\end{tabular}


Table 6: Descriptive statistics of the dataset.

\begin{tabular}{ll}
\hline Number of original tweets & 707,829 \\
Number of retweets & $3,093,026$ \\
Number of unique users & $1,000,244$ \\
Number of unique users who wrote original tweets & 323,876 \\
\hline
\end{tabular}

number of unique users, and the number of unique users who wrote original tweets.

\section{Dataset Access}

The data set is accessible through GitHub at this address: https://github.com/aseelad/Coronavirus-Public-Arabic-

Twitter-Data-Set/

To comply with Twitter's Terms Conditions ${ }^{3}$, we are unable to distribute the text of the collected data set. For that, only tweet IDs can be released and then used to retrieve the full tweet object. To do so, some tools have been developed to make the process easier; Hydrator ${ }^{4}$ is one of these options.

\section{Acknowledgements}

The author gratefully thanks Afnan abdullah Aloqaily and Djedaini abdelhak for their help in data collection.

\section{References}

Clement, J. 2020. Countries with most twitter users 2020.

Mourtada, R., and Salem, F. 2014. Citizen engagement and public services in the arab world: The potential of social media. Arab Social Media Report series, 6th edition, June.

Puri-Mirza, A. 2019. Saudi arabia: number of internet users 2023.

World Health Organization, W., et al. 2020. Coronavirus disease 2019 (covid-19): situation report, 83.

\footnotetext{
${ }^{3}$ https://developer.twitter.com/en/ developer-terms/agreementand-policy

${ }^{4}$ https://github.com/DocNow/hydrator
} 